\title{
Freehand drawing as a basic means of artistic expression in the process of educating future architects versus modern computer technology
}

\author{
Agnieszka Chęć-Małyszek \\ https://orcid.org/0000-0001-6004-0635 \\ a.chec-malyszek@pollub.pl
}

Department of Architecture, Urban and Spatial Planning, Faculty of Civil Engineering and Architecture, Lublin University of Technology

\begin{abstract}
Freehand drawing is one of the earliest and most important human skills. It is one of the simplest forms of recording thoughts and information from an early childhood, which allows to communicate without using words. It is the first verbal form of contact with the outside world by means of which feelings, emotions and desires are illustrated. It is something that allows one to see the surrounding beauty, see the details, learn about the structure and structure of matter and keep the image in memory for a long time. The article discusses issues related to the process of education in freehand drawing at the Faculty of, Faculty of Civil Engineering and Architecture of Lublin University of Technology. In this paper, the drawing is presented as a basic tool for presenting one's own design concept to future investors, which teaches perception, analysis, as well as develops creative and spatial imagination. Assuming that learning freehand drawing is the basis of all artistic activities, the article attempts to examine the essence of freehand drawing in the process of educating future architects at the Lublin University of Technology. The literature on the subject raises the issue of values conveyed through freehand drawing and compares it with contemporary, advanced computer programs.
\end{abstract}

Key words: freehand drawing, modern computer technology, means of artistic expression

The ability to draw is the source and essence of painting, sculpture and architecture itself, as well as of any presentation that falls under the senses (...). The drawer, who will become master of this skill, has in his/her hands a treasure underestimated. ${ }^{1}$

\section{Introduction}

The use of freehand drawing is a basic skill necessary for future candidates wishing to study architecture at both the Technical University and the Academy of Fine Arts. Every year, hundreds of high school graduates try to get into their dream studies in order to become an architect in the future. As you know, drawing is one of the most important skills required from the candidates for the degree in architecture, as it is the basis for any design and artistic activity. It is based on the search and the resulting errors, which makes it close to man. Nowadays, in the era of omnipresent informatization and computerization, the role of freehand drawing has significantly changed. More and more often we can come across an opinion that it is unnecessary for contemporary designers and is being replaced by advanced computer programs that quickly and easily allow for the 
representation of three-dimensional reality without any manual skills. Nowadays it is increasingly difficult to explain to students how important is a solid drawing technique, which is a trademark of a good designer and architect. The highly developed skill of using drawing allows to illustrate, in a quick and easy way, every thought, idea and idea, leading to its execution. It so happens that modern design programs are not able to replace the basic means of communication, which is freehand drawing. The key role it plays is the need to communicate and present one's artistic vision to others. ${ }^{2}$

Every creative process has always started with an initial sketch or a note from nature. To this day, nothing has changed. What is new, however, is that more and more often preliminary drawn projects are subjected to computerized graphic processing to better visualize the idea. Nowadays, freehand drawing seems to be a much more complex and multi-aspect phenomenon available for a few. It is a kind of language with which the designer-artist presents his/her vision and idea and communicates in this way with the rest of the world. It is the first tool for communication expressed through a quick sketch, diagram or concept. It allows analyzing and synthesizing the surrounding world and developing one's individual creative style. It is becoming common for freehand drawing to be replaced by a computer, however, architecture students in the first years of their studies largely use freehand drawing, as it is the only one that enables them to develop creative design abilities.

This article refers to drawing as one of those timeless human skills that contribute to the development of civilization and are the basis for building material culture. It is an essential and irreplaceable element of education, upbringing and training, which teaches independent thinking. The article brings the reader closer to the essence and meaning of freehand drawing, as a process of perception, study of reality and as a primary means of presenting architectural thought, which is an important element in the process of educating architects.

\section{Drawing as an independent creative statement}

Since the beginning of the history of art, there have been excellent drawers who left behind valuable creative works. Already in prehistoric times drawing was one of the main forms of communication between people, fulfilling at the same time decorative, religious and ritual functions. Already Pliny appreciated the drawing skills of the Greek masters, who for the first time introduced the contour which proves the perfection of the painting. He believed that anyone can paint, but drawing the contours of the body and surrounding elements is one of the most remarkable skills. ${ }^{3}$

Byzantine artists gradually developed the art of drawing, which had been forgotten for a certain period of time, which in consequence contributed to the popularity of this technique, especially in miniature art. During the Renaissance, on the other hand, it was mainly used to specify the artist's idea, where painting, sculpture and architecture were defined by a common term arti del disegno, i.e. the drawing arts. ${ }^{4}$

The Gothic era caused an intensive development of freehand drawing, called the modern architectural sketch, which contributed to the identification of the architect. Such creators ensured themselves an important position in the society by deepening their technical knowledge and necessary skills. Their creative predispositions played an important role, which they could present only thanks to their ability to transfer the idea to the paper by means of sketch. Particularly important for freehand drawing was the turn of the fourteenth and fifteenth century, in which the interest in art and drawing grew, which led to an increase in the realization of architectural concepts. ${ }^{5}$

The turn of the $19^{\text {th }}$ and $20^{\text {th }}$ centuries saw a great development of different styles in drawing in Europe, which led to a deeper understanding of the characteristics of materials used at the design stage. During this period there was a diversity of styles and architects began to create bolder drawings. Drawing became a major

2 H. Mełges, "Freehand drawing as an important skill for an architect and students of architecture", [in:] M.J. Żychowska (ed.), Challenges of $27^{\text {st }}$ century. To draw, to paint or to use a computer, Vol. 2, Wydawnictwo PK, Cracow2015, 85-98; B. Makowska, "The significance of sketches in the education of architects and in the development of their professional skills", Czasopismo Techniczne. Architektura 2015, R. 112, z. 4-A, 17-24; Gomółka J., "Architectural drawing as a means of communication", Czasopismo Techniczne. Architektura 2015, R. 112, z. 4-A, 191-194.

3 Pliniusz, Historia Naturalna, translated by I. T. Zawadzki, fragment in: Disegno - rysunek u źródeł sztuki nowożytnej, Wrocław-Cracow 1961, S. 125.

4 G.Noble, Rysowanie. Klasa mistrzowska. 100 technik wybranych artystów., Arkady, Warsaw wyd. 2019, s. 9-10.

5 A. Białkiewicz, "O rysunku architektonicznym", Teka Kom. Architektura i Urbanistyka Studia Krajobrazu - OL PAN, 2006, p. 53-60. 
tool in the architect's work until the emergence of advanced graphical programs to assist in the creation of shapes that were difficult to reproduce manually. ${ }^{6}$

In the 1970s drawing was distinguished as a fully sovereign field of visual arts, where practically every work of art, architectural design or drawing, was made using perspective. Among the artists creating in the last five hundred years, considered to be masters of drawing, one can mention: Michelangelo, Leonard, Rafeal, Titian or Hieronim Boch. In works of all the above mentioned artsts, the drawing was the absolute basis of everything. It allowed not only to experiment, but also to create much more painterly works. Other great artists, like Rubens, used drawing to develop their complex compositions, and Clauidi Lorrain used it to create visual catalogues of his own drawing compositions. All these less and more famous artists used it as an integral medium in their work, where each of them used it according to their needs and individual style. Without a doubt, Vicent van Gogh's work provides most examples of how artists often used drawing to satisfy their needs and desires. ${ }^{7}$

The $20^{\text {th }}$ century saw the charismatic work of Pablo Picasso, whose experimentation led to the discovery of new possibilities of drawing, painting or graphics. Other artists could not match him. His main rival, however, was Henri Matisse, also considered a giant artist. Both of them made thousands of drawings and although not all of them were great, the excellence of the best ones overshadows all their competition. ${ }^{8}$

In 1915, teaching drawing from nature was nothing new in public schools. It was considered to be one of the most important subjects that significantly influenced the development of young people's imagination. Drawing was treated as a form of recording simple visual insights, complex ideas and imaginations. It included both the material and visible world, as well as the world of thoughts, ideas and views, essential features of structure, construction, function and proportion. ${ }^{9}$ It was often regarded as a method of thinking and not just a mechanical action, as it allowed the views and ideas to be combined while maintaining a specific form of expression.

Since the beginning of history, drawing and architecture have been closely linked. It is enough to mention the drawings of Mies van der Rohe or Antonio Sant'elia, in which architecture dominates in the form of drawing, exploding with the canon of colors and spatial forms. The turn of the 1970s for many artists, such as Mies van der Rohe and Antonio Sant'elija, were the years of greatness in which they reached the apogee of their creativity using a simple tool such as a pencil. ${ }^{10}$ Multiplicity, multiformity and multifunctionality of drawing have been recognized, as it is used not only by architecture designers but also by constructors, mathematicians and physicists. Flexible and fragile drawing has become a carrier of stimuli for the imagination, a rotation of thought-provoking concepts and a cipher with ambiguous message content. Thanks to its unpretentiousness and modesty, drawing gained a new position and value and gained autonomy, thus expanding its functions, space and form. ${ }^{11}$

It is worth noting that the drawing was created out of a need and its teaching for many years was purely practical. The first architectural schools were connected with the Academy of Fine Arts, complementing each other. The twentieth century saw to its appearance also at the Polytechnics, where drawing, however, had a lower rank than at art schools. ${ }^{12}$

The art of using freehand drawing is a personal act of creative human activity, where it is often sketchy and schematic. It maps a perspective, draws points and, above all, sets a given space on paper. The act of drawing often becomes the beginning of a great work. It allows discovering the true, inner idea of a given creator. Drawing, sketching or painting allows to get to know and look closer at the works of great artists, who often become a valuable source of inspiration. Thanks to the simplicity of the technique, there are no intermediate stages between the concept of the drawer and the materialization of his vision. The hand holding the tool can

6 N. Benkari, M. Boudidah, Architectural education and cultural context in the use: challenges and opportunities, Alma Cipta vol 7 (2), December 2014, 51-62

7 G. Noble, Rysowanie. Klasa mistrzowska... p. 12-15.

8 llab, p. 16.

9 R. Balcerzka, M. Ozrechowski, J. Pętkowska-Henlek, M. Suffczyński, A. Sufiński, T. Trzupek, Rysunek architektoniczny w praktyce, czyli jak patrzeć ze zrozumieniem, PWN, Warsaw 2019, p. 73.

10 Danish studio BIG and its publication Yes is More, Herzog \& de Meuron or Jean Nouvel: "Architektura i komiks”, Architektura-Murator 11, Murator, Warsaw 2010, p. 1.

11 B. Narolska, „Sztuka”, Available: https://www.profesor.pl/publikacja,10846,Artykuly,Rysunek-jako-samodzielny-pelnowartosciowy-obszartworczy [Accesed: 27 Fabruary 2015]

12 Ilab. 74. 
respond directly to any vibration of emotions, change of mood or course of thoughts. The close relationship between the activity of drawing and biological mechanisms makes it only personal, where drawing becomes a unique work, created only in one copy.

The concept of drawing is most often analyzed in terms of the psychology of seeing, because it consists in reproducing real and imagined objects on any plane. It also includes aspects of graphic imaging and has the characteristics of a structural drawing. Structural drawing is defined mainly by graphic aspects, understanding and analysis. It is a record of geometric forms, which allows a comprehensive understanding of the subject and a graphic presentation of the internal structure of an object. The ability to draw is especially connected with thinking from the moment of birth through growing up, cognition leading to independence and maturity. ${ }^{13}$

Nowadays, drawing has become an independent and full-value creative image, which can be found everywhere and its scope becomes immeasurable. It is no longer just a mimetic process revealing the artist's emotions, but an understanding of aesthetic values in every most unexpected form of drawing. The boundaries between artistic and non-artistic drawing are also blurred and they are no longer clear. The formulation of an intellectual and emotional problem, consisting in the visual organization of all components of a work of art, became decisive in this respect. The use of different tools, types of lines, relations of form, character or size, plays a strictly defined role in the drawing, where the mutual relations among these components determine whether the work contains this kind of internal tension. It may seem, therefore, that the way in which all the components of the work are organized is individual and reveals itself at the level of the drawing, influencing the value of the project. ${ }^{14}$

The role of drawing has changed radically over the recent years. Its range has expanded considerably and it has been elevated to the rank of an independent and full-fledged medium. Drawing has ceased to be treated as a side activity and has become more comprehensible to a wide audience. It was considered to be an attitude of almost every visual expression on which one builds, nowadays using different technologies and tools, completely different structures.

In some cases, the drawing has not changed significantly, as it still operates with a line, stroke, valor or stain and is an independent and complete creative image. The canons of proportions of the characters in the old days, where they are still a rich source of knowledge about man and his surroundings, have not changed either. It is an instinctive and deeply inborn medium. It is a universal and versatile art, highly practical as it allows anyone with a pencil and a piece of paper to express themselves creatively in a fairly quick and easy way. It is counted among the earliest records of exchange of thoughts, ideas and ideas known to us. Despite the emergence of modern computer technologies and new methods of artistic expression, drawing still retains its unique place as a means of individual creative expression. It is a universal, universal and practical form of art. It is thanks to it that the spatial imagination is shaped, which influences the ability to note and create ideas. It is one of the quickest and most direct forms of expression at the stage of the presentation of an idea still after it will be reproduced in detail using a computer.

\section{Convention - vision - purpose of freehand drawing}

The education and development of artistic skills of past architects is mainly based on learning to observe phenomena, where reality is analyzed. Learning to draw starts with observation and turns into the creation of a work of art, for which language is necessary to express form, color, space or light. These are the values that characterize an architectural work, which is based on drawing and the related methods of visualization. Learning to draw is a very important part of the course of study of architecture, because it is necessary not only at the stage of design, but also to document reality.

The main aim of the classes in drawing and painting in the faculty of architecture is to exercise spatial imagination, artistic sensitivity and sense of proportion on the paper surface. These classes are designed to teach sensitivity to value and color as a decorative element of the architectural form. They enable free and creative expression, which significantly influences the shaping of personality of future architects. 
One of the basic exercises during drawing and painting classes at the Faculty of Architecture at the Lublin University of Technology is the study of still life, which allows an in-depth knowledge of a given object's structure, matter, shape or color. At the same time, it is an excellent way to practice the drawing workshop necessary to solve more and more complex artistic issues in the architect's further work. Drawing from nature consists of detailed observation and analysis, leading to the realization of the task set. It teaches us a completely different approach, when we can really look at a given building, alley or situation, we are able to remember many more details as our head remembers through the hand. Each such drawing is also associated with a lot of emotions that accompany a given place at the time of drawing, smells from nearby cafes, the climate of the area or the sounds of the city.

The first topics for students consist mainly of simple geometric arrangements of solids, which over time turn into multi-element and dynamic still life compositions. (Fig. 1,2) During the classes, there are also exercises in the imagination, which aim to stimulate creativity, the ability to express a specific topic and search for their own solutions only with the help of imagination. (Fig. 3,4) Students use a variety of drawing, painting and graphic techniques during the class. They learn to correctly grasp proportions, structure, scale or detail and to correctly place a given form in space. The classes also include exercises related to the acquisition of the ability to correctly draw the proportions of the human body. Painting classes allow conscious and creative use of color. Students gain knowledge of the theory of color phenomena, the theory of composition of its types and understanding the impact of individual colors and their application in architecture. In turn, the outdoor classes, where the students carry out landscape painting exercises, allow an impression of architecture, used at a later stage of design. (Fig. 5, 6, 7, 8)

Before the appearance of advanced computer programs, the drawing served as an element of communication between the designer and the investor. It was based on observation, drawing from nature by independent analysis of the observed phenomenon. Sketching was not only a transfer of the building on a sheet of paper, but also a conscious analysis and learning about the object, its shape, function or structure. It is working with the client, who sees the certainty of thoughts and no hesitation of the architect.

Nowadays we live in the times when every designer-architect must develop his/her own visual language. Freehand drawing allows to use one's own separate drawing style and not to succumb to the conventional scheme. The task of a drawing project is not, therefore, to map a given reality, but to create a completely new reality or to show a surprising transformation. It allows to quickly express the form, color, space or light, which is sometimes difficult to visualize with modern computer equipment. Nowadays, more and more often a project is treated as a product and not a work of art, and all this by a widely developed commercialization. A drawing project appears more and more often as an aesthetic protomaz created using a computer, instead of a synthetic impression sketch. More and more rarely young designers use pencil and card, which are an inseparable part of place, time and above all humanity.

Nowadays, the process of education of future architecture students is still changing, new subjects are added, which encourage them to look for independent and creative design solutions. However, freehand drawing remains an irreplaceable and unchanging basis for future architects. Many classes are still conducted in the manual form, because it allows to develop manual and design skills, and allows to learn about the form and styles of architecture, which influence the formation of cultural awareness. On the other hand, the first drawing sketches often serve as a basis for a dialogue between the artist and his own work, which leads to a deeper and deeper search for new forms of individual creative expression.

Teaching freehand drawing is an important part of the architecture education at both the Academy of Fine Arts and the Technical University. It plays a very important role not only in the design process, but also in documenting nature and history. It is considered to be one of the oldest languages of creative expression. It is one of the most popular artistic techniques, thanks to which, with the use of specific creative tools, visual compositions on a given plane are created. Drawing is an irreplaceable tool for presenting one's own design concept to future investors, it allows communicating with the environment through one's own artistic vision. ${ }^{15}$

15 H. Mełges, "Freehand drawing as an important skill for an architect and students of architecture", [in:] M.J. Żychowska [ed.], Challenges of $27^{\text {st }}$ century. To draw, to paint or to use a computer, Vol. 2, Publisher: PK, Cracow2015, 85-98; Makowska B., "The significance of sketches in the education of architects and in the development of their professional skills", Czasopismo Techniczne. Architektura 2015, R. 112, z. 4-A 17-24; Gomółka J., "Architectural drawing as a means of communication", Czasopismo Techniczne. Architektura 2015, R. 112, z. 4-A,191-194. 


\section{Using artistic skills at the design stage}

The perspective, of all the rules of freehand drawing, is one of the best known, desirable and useful skills required from future architects. Leone Battista Alberti, in his treatise Della Pittura (About Painting), proved that perspective is one of the most effective methods of presenting three dimensions on a two-dimensional plane, while drawing is meant to show the viewer what he/she has not yet seen in the most original and surprising way possible. ${ }^{16}$

The second important issue is the knowledge of chiaroscuro, which allows the drawer to describe the gradation between black and white. It consists in capturing the light of the paper by adding darker characters with one tool. Drawing from nature is an in-depth observation of the subject and an attempt to recreate it on the flat surface of the paper, where the real space is the one around us, which we refer to while drawing. ${ }^{17}$

Skillful application of contour or edges allows making the drawing look flat or three-dimensional. Paul Klee emphasized that drawing is like taking a line for a walk, where the line often serves as a contour that wraps a silhouette or an object. ${ }^{18}$ The structure of a contoured drawing refers to a specific skeleton architecture that connects certain parts of the area.

On the other hand, knowledge of the rules of composition allows for proper organization of the space using simple geometric shapes and proper layout of these elements on the paper surface. ${ }^{19}$

Eyesight is the most developed and at the same time the most complicated human sense used in freehand drawing, as it subjects the seen and processed image to in-depth analysis. The ability of students to use the sense of sight while drawing is closely related to the process of perceiving, processing and interpreting reality. They make an in-depth analysis of their own creative work, which consists of both what they see with the naked eye and what they know about the presented (drawn) object. Skilful and insightful observation allows showing the real space on the basis of one's own experience and acquired knowledge in the most correct and interesting, sometimes even surprising, way. ${ }^{20}$

A very important element at the stage of learning to draw is sketching, because it allows to quickly create creative solutions, where in the multitude of lines, something yet unknown may emerge. Sketch very often functions as an independent artwork and has unlimited possibilities. It allows creating original realizations that come out for a typical understanding of drawing. It is often full of the content related to the experiences of an individual and not only a reflection of the image. It filters the existing reality, taking into account only important elements. A sketch is often used in the open air, because it allows to save the seen moment (image) in a fast and simple way. It belongs to the most beautiful, as it is the most personal, forms of graphic expression, It most accurately shows a certain fragment of reality far from realism. A sketch in a subjective way shows an object in space being an end in itself in an intuitive and random way. ${ }^{21}$

A freehand drawing can be considered as a certain state of mind, which does not have to be referred to in the sketch, as it is a brief description of the phenomenon of the project being developed. In a schematic way it presents an outline, concept or composition elements used in a later realization. Sketching is the ability to create mental shortcuts and translate them into plastic language, which often turns out to be even better than the final work.

Learning the skill of studio drawing is also important for architecture students, It consists of careful study of spatial relations and surface analysis of the subject. Freehand drawing allows an individual observation and analysis of the perceived object and then drawing the form, proportions, texture, chiaroscuro, construction or texture. A studio drawing is a thorough structural and surface analysis of the object, which provides important

16 L.B. Alberti. Renesansowa teoria piękna, cz. 1 Available: https://niezlasztuka.net/o-sztuce/leon-battista-alberti-renesansowa-teoria-pieknacz1/ [5 April 2017].

17 G. Noble, Rysowanie. Klasa mistrzowska. 100 technik wybranych artystów, Arkady, Warsaw, published: 2019, p. 16-28.

18 Ilab. 30-34.

19 Ilab p 35-38.

20 llab p. $125-130$.

21 R. Balcerzka, M. Ozrechowski, J. Pętkowska-Henlek, M. Suffczyński, A. Sufiński, T. Trzupek, Rysunek architektoniczny w praktyce, czyli jak patrzeć ze zrozumieniem, PWN, Warsaw 2019, p. 180-190. 
information about the object, which is a reflection of reality. It is, in a way, only a means to achieve an assumed goal, which is mainly based on working out one's drawing skills. ${ }^{22}$

Freehand drawing is characterized by a lack of precision and artistic freedom, which significantly distinguishes it from the effects of computer work, and thus will bring specific and timeless value. Freedom and flexibility often translates into freedom of thought and allows one to quickly save fleeting ideas. It teaches students to see, be attentive and translate the real view into a flat sheet of paper. It is a universal skill that is used in the same way when drawing a character, car, tree or architecture. It allows students to perceive independently, express their own thoughts and emotions coming from outside. It allows one to find their own individuality and creativity, as well as helps to understand oneself and the surrounding reality. It is a simple form of communication between the participants of the design process, cpnstituting a starting point for a more complex and elaborate project. It is a graphic record of complex information about space.

What is important in the drawing is what the author wants to express using the available means and techniques. It consists in examining spaces and shapes between objects, which allow to change the way of perceiving and discovering a given object anew. Drawing based on his own previous sketches is a very practical tool, because it allows to transfer an object from a small format to a large one, changing the technique or form. It is not only a learned set of graphic skills, but an overall process of perceiving and learning about reality through the senses. It directly influences the shaping of the personality of the future architect by individual recording in the graphic form of the observed environment using long lines, short lines or spots.

A freehand drawing is a description, analysis and interpretation of the environment. It starts with a study of the object through realistic interpretation where it turns into graphic abstraction over time. God invented paper so that the architect could draw stated Alvar Aalito. Drawing is a process of technical skills of the creator, a state of mind subordinated to the relationship between man and nature. It is the crossing of borders between the known and the unknown, visible and invisible. Often it is not an end in itself, but an analytical record of everyday life stopping the passing by, thanks to which we see shapes, colors or forms, and can analyzy the reality around us. $^{23}$

Drawing is used by the architect not only to impress emotions or to reconstruct the reality seen, it is a deuce of spatial imagination, the science of sensitivity to shapes and colors is the science of artistic culture. It allows to penetrate the object, where the physical and mental analysis of the features of the observed space takes place under the account of mood, proportions, character or color. It also has an important cognitive function, teaches the space of a given project and contributes to the constant learning of oneself, human abilities and limitations. It influences the harmonious development of a human being throughout his or her entire life.

Learning freehand drawing during the architecture studies allows to improve the artistic skills of future architects. It allows them to acquire basic skills of presenting architectural space and its surroundings using their hand. It teaches to understand the spatial dependencies of the surrounding environment, the construction of the geometric form, not forgetting about the simultaneous artistic and creative development. It allows to acquire the ability to present design ideas, own ideas in the form of intentional sketches - simplified, as well as legible imitations of the concept in an appropriate scale and form. It allows a skilful use of perspective, creating details or wall views. It is a specific work of art, which can become a decorative element or a hallmark of a given place.

\section{Freehand drawing versus modern computer technology. (Pencil versus computer)}

When we talk about freehand drawing we mean the whole process in which there is a close relationship among the brain, the eye and the hand. Freehand drawing is the oldest way to formulate human expression, it is a very practical and useful medium. It is the most independent element of art, characterized by unlimited inventiveness and resistance to the dangers of scheme and conventionality. Computers, television, photography or advertising graphics, which surround the man from all sides, constantly attack the eyes, impose consciousness and subconscious with great force, dulling our sensitivity. On the one hand, the highly developed technology 
1)
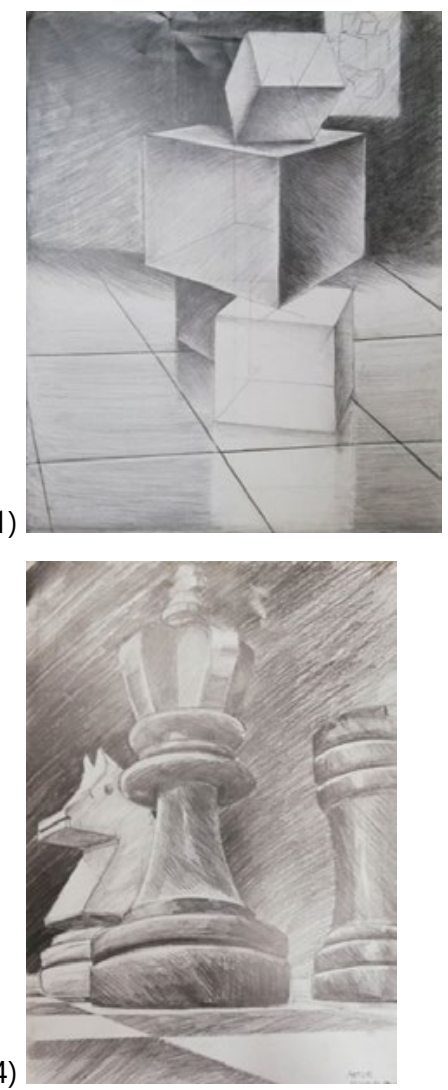

2)
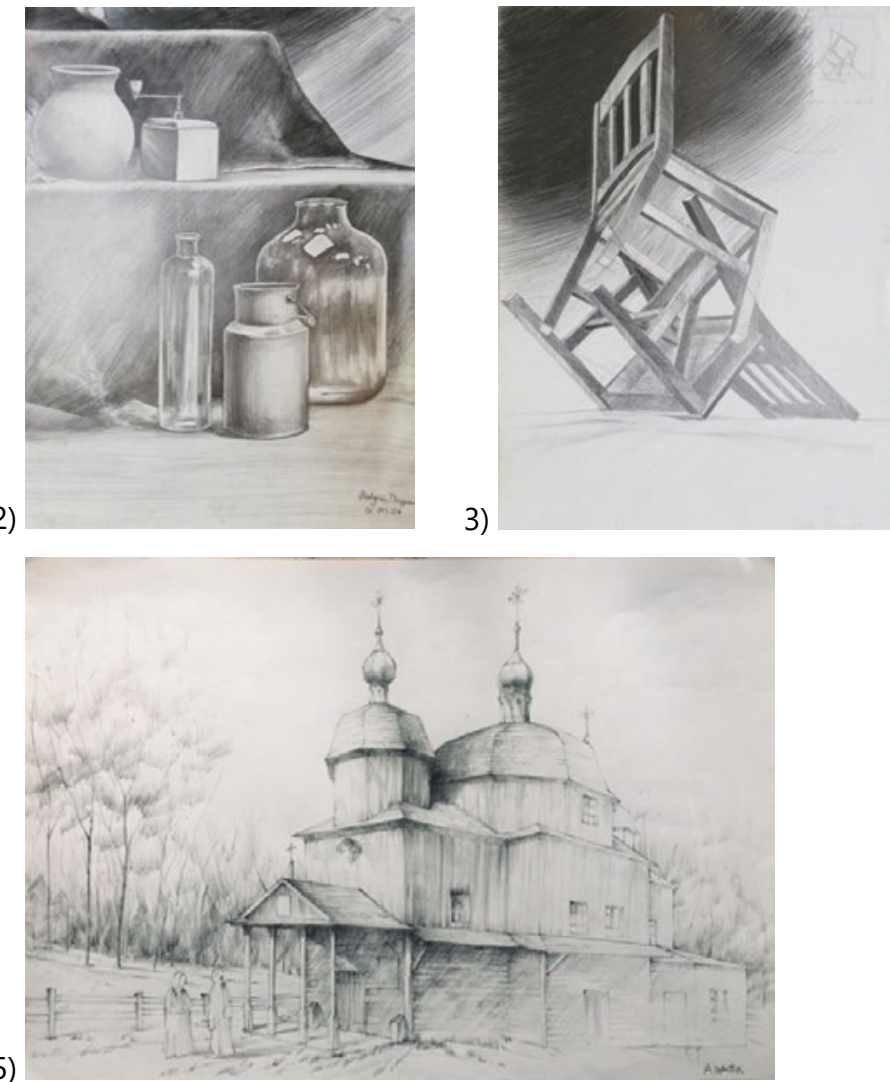

5)

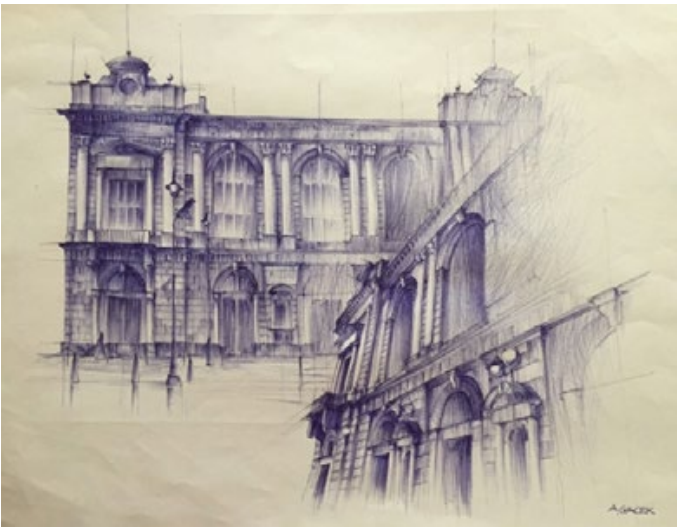

6)

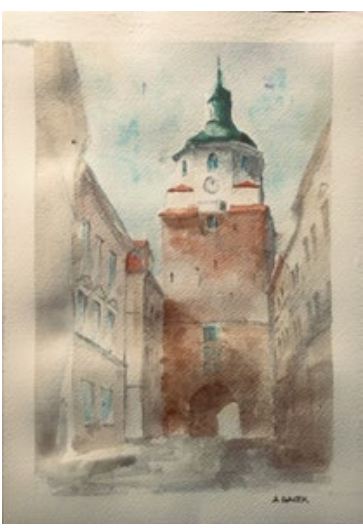

Fig. 1, 2, 3, 4, 5, 6, 7, 8. Sample topics of work carried out during the first year of the Architecture course at the Lublin University of Technology during drawing and painting classes and outdoor exercises. 
allows drawing thoughts using a graphical tablet or computer mouse, but it is also a hand stimulated recording. In this proces, there is no material cause-and-effect relationship between work, brain, muscles, eyes and tools and the substrate. Modern computer technology allows undoing the activity, erasing or easily transforming it, which, however, does not provoke a deeper cognitive analysis, but only a mechanical action. The advanced programs to design at an early stage of education often prevent the process of learning the world by studying the form, texture or material of a given surface. Moving only within the space of a three-dimensional computer simulation disturbs the process of learning about the structure of external world elements. Freehand drawing is a complex intellectual, spiritual and technical process that cannot be fully replaced by a computer. It is also not important what kind of tool we choose, but it is essential that it is an accurate record of essential features of structure, construction, functions and proportions of a given space.

The first half of the $21^{\text {st }}$ century was the ubiquitous computerization and digitization of design processes, which led to the spread of the architectural profession. This profession has become accessible to an ever-wider group of people for whom freehand drawing has been an insurmountable barrier so far. A computer does not have human qualities such as creativity, sensitivity or aesthetics, without which it is impossible to become a good architect. Such features as spatial imagination, the ability to observe and transfer objects to the plane can only be done by a human being. It turns out that no modern technology can fully replace man, his personality and creative creativity. Freehand drawing is closely related to the ability of abstract thinking. One cannot express himself/herself graphically if one does not acquire good drawing skills before. It is thanks to it that various skills and abilities are stimulated already in early childhood, which are the basic function of understanding the world around us.

Freehand drawing is for most architects the beginning of their visions, it turned out to be an excellent medium for documentation, but above all it became a method of intellectual concentration. It allows for reflection and creative action, which is difficult to achieve using only a computer. Man, by direct contact with an object or nature is able to deeply learn the structure, function, texture or smell. These are valuable and personal experiences, which cannot be felt through a computer screen. Advanced computer technology takes away creativity and often slows down thinking processes because it suggests ready-made solutions and thus destroys creative thinking. The consequences of such actions can lead to the creation of projects that do not meet the relevant architectural, construction and social standards. ${ }^{24}$

Learning to draw by hand has a huge impact on shaping the spatial imagination of future architects. Reproducing objects from nature allows one to acquire the ability to graphically record ideas from one's imagination in the form of sketches on paper. Freehand drawing is one of the fastest and most direct tools necessary at the creative design stage. It consists in creating the form of the project from a point, through lines, surface, to the creation of three-dimensional image space. This type of practice is used by older architects, while younger ones often consider freehand drawing an unnecessary skill. This is due to the fact that from a very young age they use electronic media, flat screens, which makes them difficult to imagine the space. Frequent use of laptops, smatphones or tablets interferes with the process of three-dimensional vision, which results in problems with drawing from nature, correct alignment of line directions or perspective, which blocks the ability to see and process images. Drawing is an area of activity, a place where thoughts are formulated at the level of its physical structure, which is responsible for all its components, including color, which seems to lose its expressive value here in favour of information.

Many years have passed since the technological revolution in drawing and a computer should not be treated as a threat to freehand drawing. Nowadays, it is an excellent tool to assist in design. Although it may seem that freehand drawing has become a utilitarian tool with very sophisticated tasks, yet it is not. It still has an important communication function, as a simple graphic message, which allows saving a lot of easy-to-read information (e.g.: pictograms) in a relatively fast way. At the design stage, it allows a quick and easy way of expression, where a few lines can effectively replace many sentences. It allows an in-depth analysis of the physical and mental characteristics of space and a deep (detailed) understanding of the object. It allows materializing in the form of a drawing, an idea born in the imagination and pour it on paper. 
Nowadays, more and more often students, wishing to present their idea, choose advanced computer programs, which are yet not able to replace a creative handcrafted concept. Additionally, these programs significantly limit imagination and free creation, often offering ready-made solutions. The consequence of this is a lack of ability to present one's own creative idea in a drawing form.

Nowadays, in such computerized times it is rare that hand-made visualizations can compete with advanced computer programs. Today's world is focused on image, reproduction and transformation and not on creating with the use of individual features of creative activity. Without a doubt, a computer is a very useful tool to support the creative work of an architect, but only freehand drawing allows one to truly look into the past and create an unforgettable future. All this is possible at the stage of design, creation and creative activity using freehand drawing. It allows to present the most important features of the project, creates a three-dimensional impression on a flat surface, shows the beauty, harmony and spatial order of the designed area. Freehand drawing represents a longing for uniqueness, which combines originality with the need for intimacy and privacy. It liberates freedom of gesture, individual expression leading to the most personal expression, not adhering to any conventions.

The specificity of the design is based on a special sensitivity to the environment, which is possible with direct contact. And although modern technologies give us great opportunities to present our ideas, still many designers choose freehand drawing, perhaps this is due to the fact that it is an irreplaceable method to convey the essence of their ideas.

Freehand drawing is the oldest way of formulating human expression, it is a very practical and useful medium. It is the most independent element of art, which is characterized by unlimited inventiveness and resistance to the dangers of scheme and conventionality. Computer, television, press photography or advertising graphics, which surrounds the man from all sides constantly attack the eyes, impose themselves on the consciousness and subconscious, and with great force dull human sensitivity.

\section{Summary}

Learning to draw is a continuous process of learning to observe, explore and discover the environment. Freehand drawing is not only a tool for presenting the final version of a project, but also a basic means for its realization. Over the last years, its form and its earthy character has been greatly affected, as often a pencil is replaced by more modern electronic tools, but this does not mean that it is no longer needed. Its role has changed, but not its importance as a basic means of communication, which significantly affects the development of the imagination, so important in the design process. Teaching freehand drawing to architecture students plays a key role in the development of aesthetic sensitivity, composition, spatial imagination, and technical skills necessary for future professional work.

Drawing from nature develops the sense of observation, teaches to see the rules that determine the principles of drawing. Only by drawing from nature is it possible to find confirmation of all the theories and rules in practice, which allows to understand them. Freehand drawing is about lights, shadows, solids, space, colors, perspective and countless forms and topics to draw. It is an infinite number of issues, waiting only to be confronted with. It is an infinite path of artistic development. One will not find all this in any photo.

The learning process of a human being consists of constant repetition of certain behaviors, activities in a practical way until a given skill is acquired. The same is true of drawing, only the numerous hours spent in the studio, where students personally, using various techniques, make drawings, are able to teach future architects how to create valuable and demanding projects. It should be remembered that the use of digital technologies must go hand in hand with the ability to present a design idea. The basis of the skill of a good architect is drawing, which is accompanied by pure pleasure, which is an excellent basis for creative activity and creation. 


\title{
Bibliography
}

[1] Alberti L. B.,„Renesansowa teoria piękna, cz. 1" Available: https://niezlasztuka.net/o-sztuce/leon-battista-alberti-renesansowa-teoria-piekna-cz1/ [5 April 2017].

[2] Balcerzka R., M. Ozrechowski, J. Pętkowska-Henlek, M. Suffczyński, A. Sufiński, T. Trzupek, Rysunek architektoniczny w praktyce, czyli jak patrzeć ze zrozumieniem, PWN, Warsaw 2019, p. 7, 170-176.

[3] Białkiewicz A., O rysunku architektonicznym, Teka Kom. Architektura i Urbanistyka Studia Krajobrazu - OL PAN, 2006, p. $53-60$.

[4] Benkari N., Boudidah M., Architectural education and cultural context in the uae: challenges and opportunities, Alma Cipta Vol 7 (2), December 2014, 51-62.

[5] Gomółka J., Architectural drawing as a means of communication, „Czasopismo Techniczne. Architektura” 2015, R. 112, z. 4-A,191-194.

[6] Hansen D., Architecture and pencil, [w:] M.J. Żychowska [ed.], "Challenges of $21^{\text {st }}$ century. To draw, to paintor to use a computer", Vol. 1, Wydawnictwo PK, Cracow 2015, 48-49.

[7] Hollanda de F., Dialogi rzymskie (1548), fragment w: „Disegno - rysunek u źródeł sztuki nowożytne”, p. 125 Available: https://www.szkolnictwo.pl/szukaj,Rysunek [Accessed:20 November 2015].

[8] Makowska B., The significance of sketches in the education of architects and in the development of their professional skills, "Czasopismo Techniczne. Architektura" 2015, R. 112, z. 4-A, 17-24.

[9] Mełges H., Freehand drawing as an important skill for an architect and students of architecture, [w:] M.J. Żychowska (red.), Challenges of $21^{\text {st }}$.

\section{Rysunek odręczny podstawowym środkiem wyrazu plastycznego w procesie edukacji przyszłych architektów a współczesna technologia komputerowa}

\begin{abstract}
Streszczenie: Rysunek odręczny należy do jednych z najwcześniejszych i zarazem najważniejszych umiejętności człowieka. Zaliczany jest do najprostszych form zapisu myśli oraz informacji już od wczesnego dzieciństwa, który pozwala komunikować się bez użycia słów. Jest on pierwszą, werbalną formą kontaktu ze światem zewnętrznym za pomocą, którego ilustrowane są uczucia, emocje i pragnienia. Jest czymś, co pozwala zobaczyć otaczające piękno, dostrzec szczegóły, poznać budowę i strukturę materii i na długo zachować obraz w pamięci. W artykule poruszono zagadnienia związane z procesem kształcenia w zakresie rysunku odręcznego na kierunku architektura na Wydziale Budownictwa i Architektury Politechniki Lubelskiej. W niniejszej pracy rysunek został przedstawiony, jako podstawowe narzędzie umożliwiające zaprezentowanie własnej koncepcji projektowej przyszłym inwestorom, który uczy spostrzegania, analizowania oraz rozwija wyobraźnie twórczą i przestrzenną. Przyjmując, że nauka rysunku odręcznego stanowi podstawę wszelkich działań artystycznych, w artykule podjęto próbę zbadania istoty rysunku odręcznego w procesie kształcenia przyszłych architektów na Politechnice Lubelskiej. W literaturze przedmiotu poruszona została kwestia wartości przekazywanych za pośrednictwem rysunku odręcznego oraz dokonano porównania go ze współczesnymi, zaawansowanymi programami komputerowymi.
\end{abstract}

Słowa kluczowe: rysunek odręczny, współczesna technologia komputerowa, środek wyrazu plastycznego 